Al-Manhaj: Journal of Indonesian Islamic Family Law, 3 (2), 2021: 191-202

ISSN: 2715-003; E-ISSN 2714-5514

DOI: http://dx.doi.org/10.19105/al-manhaj.v3i2.5572

\title{
Analisis Perilaku Nikah Siri Masyarakat Pamekasan Sebelum Akad Nikah di Hadapan Pejabat KUA
}

\author{
Asyhari \\ (Universitas Sunan Giri Surabaya, asyharizubair@gmail.com)
}

\begin{abstract}
Abstrak:
Kajian ini mengungkap fakta anomali masyarakat, melakukan pernikahan siri yang dilakukan beberapa hari atau bulan sebelum pernikahan secara resmi dilakukan di hadapan pejabat Kantor Urusan Agama (KUA). Setidaknya ada tiga alasan pernikahan siri tersebut dilakukan, yakni sebagai antisipasi terhadap asumsi keliru masyarakat yang menilai pertunangan berkonsekwensi seperti akad nikah. Kedua, menghindari terjatuhnya kedua mempelai ke dalam perbuatan seperti zina dan lainnya. Ketiga, sebagai upaya menyegerakan pernikahan karena waswas kegagalan prosesi pernikahan. (This study reveals the fact of the community anomaly, carrying out a serial marriage which is carried out a few days or months before the marriage is officially carried out in front of the official of the Office of Religious Affairs (KUA). There are at least three reasons for the unregistered marriage to be carried out, namely as an anticipation of the wrong assumptions of the public who judge that engagement has consequences such as a marriage contract. Second, avoiding the fall of the bride and groom into acts such as adultery and others. Third, as an effort to hasten the marriage because of concerns about the failure of the wedding procession.)
\end{abstract}

\section{Kata Kunci:}

Nikah siri, perilaku masyarakat, sosiologi hukum

\section{Pendahuluan}

Sebagaimana layaknya kehidupan yang selalu melestarikan keturunan, maka demikian pula manusia ketika menjalankan 
kodratnya. Seorang anak manusia melakukan jalinan dengan lawan jenisnya sehingga menjadi ikatan satu sama lainnya, yang kemudian disebut dengan pernikahan. Karena itulah agama perlu untuk mengaturnya dalam sebuah hukum pernikahan. Karena pernikahan itu adalah urusan perdata yang luas, yang tidak hanya berkisar kehidupan rumah tangga dan keturunan, tapi juga perkenalan antara suatu kaum dengan kaum lainnya. ${ }^{1}$

Sebuah fakta di masyarakat bahwa terjadi pernikahan siri yang begitu merebak. Meskipun sudah nyata efek negatif bagi tata kehidupan, namun itu tidak membuat perilaku nikah siri tidak lenyap, bahkan selalu saja terjadi. Padahal berbagai berbagai penelitian yang diangkat dari realita sosial dan hukum masyarakat telah membuktikan bahwa pernikahan macam ini menimbulkan prahara bagi istri dan anak. Di antaranya adalah tidak adanya hak sipil bagi istri dan anak, berupa akta lahir, akta nikah hingga hilangnya hak kewarisan dan lainnya.

Hal ini tentu tidak mengatakan nikah siri dalam konteks sah tidaknya menurut hukum Islam. Karena nikah siri itu dilakukan sesuai dengan rukun dan syarat yang telah ditetapkan oleh islam dan negara. Hanya satu masalahnya, bahwa nikah siri ini tidak didaftarkan ke KUA, sehingga diistilahkan nikah di bawah tangan. Sebagaimana yang sudah maklum bahwa nikah siri ini adalah pernikahan yang tidak tercatat dalam dokumen negara, sehingga sangat wajar jika hak sipil keperdataan menjadi terabaikan. Para pelakunya mungkin melihat nikah siri sebagai hal positif atau hal biasa. Padahal jika kemudian dikaji lebih jauh, banyak efek negatif muncul yang tak pernah terbayangkan sebelumnya. Bahkan mungkin temuan efek yang tak pernah tercatat dalam penelitian apapun sebelumnya.

Akan tetapi fakta unik lainnya ditemukan bahwa ternyata ada perilaku nikah siri yang dilakukan sebelum pernikahan resmi yang dilakukan di hadapan pejabat KUA (Kantor Urusan Agama). Nikah siri ini dilakukan tidak lama sebelum 'akad resmi' digelar. Dari sekian kasus dijumpai bahwa akad nikah siri ini terjadi empat bulan, dua bulan, sebulan, bahkan 2 minggu sebelum 'akad resmi'. Hanya saja ini masih akan ditelusri lebih lanjut. Pertanyaan pun mengemuka, mengapa masih melakukan nikah siri jika memang direncanakan

${ }^{1}$ M. Dahlan R., Fikih Munakahat, (Yogyakarta: Deepublish, 2016), 
'nikah resmi'? Sehingga fakta inilah yang kemudian menjadi fokus kajian pada tulisan ini.

\section{Konsep Pernikahan}

Dalam hukum islam, sebelum melangkah pada jenjang pernikahan secara serius, dianjurkan melakukan khitbah (lamaran) terlebih dahulu. Hal ini sebagai mukaddimah (pembukaan) untuk melangkah pada tingkatan yang lebih serius. ${ }^{2}$ Pernikahan merupakan asal kata dari nikah yang tak lain kata serapan dari bahasa arab, نكاح. Secara bahasa nikah berarti mengumpulkan dan condong. ${ }^{3}$ bisa juga nikah diartikan sebagai kata yang mengungkapkan hubungan seksual dan akad sekaligus.

Hukum menikah adalah sunnah atau dianjurkan bagi orang membutuhkan pernikahan tersebut. Kebutuhan tersebut bisa mengarah pada kebutuhan jasmani atau biologis sebagaimana layaknya makhluk hidup, atau kebutuhan jiwa mendapatkan kasih dan sayang. Kebutuhan ini bisa menjadi anjuran menikah bila memiliki kemampuan membayar mahar atau maskawin. Dengan kata lain jika tak mampu membayar mahar, maka tidak dianjurkan menikah.

Pernikahan (baca: perkawinan) adalah sunnatullah yang menghampiri hampir semua makhluk hidup, termasuk manusia. Hanya saja manusia sebagai makkluk beradab memiliki cara yang agung dalam mewujudkannya. Tidak seperti aktivitas perkawinan yang dilakukan oleh binatang. Manusia memiliki prosesi yang telah diatur oleh norma agama maupun sosial.

Nikah secara syara' bermakna akad yang mengandung kebolehan kebolehan istimta' / bersenang-senang dengan hubungan seksual, percumbuan, ciuman dan lainnya. Menurut pakar ushul fiqh dan bahasa, pernikahan ini adalah hubungan seksual secara hakikat, namun bermakna secara majas.

Sehingga dengan demikian pernikahan atau perkawinan dapatlah dipahami sebagai akad perjanjian antara seorang laki-laki dengan seorang perempuan dengan maksud saling memberi dan

2 Wahbah al-Zuhaily, Al-Figh al-Islami wa Adillatuh, (Maktabah Syamilah, tt.), IX, 6492

${ }^{3}$ Muhammad ibn Qasim al-Ghazi, Fathul al-Qarib, (Maktabah Syamilah, tt.), 224 
mengambil manfaat dari keduanya untuk membentuk sebuah keluarga yang saleh dengan syarat dan ketentuan yang telah ditentukan menurut syariat agama.

Al-Qur'an menjelaskan:

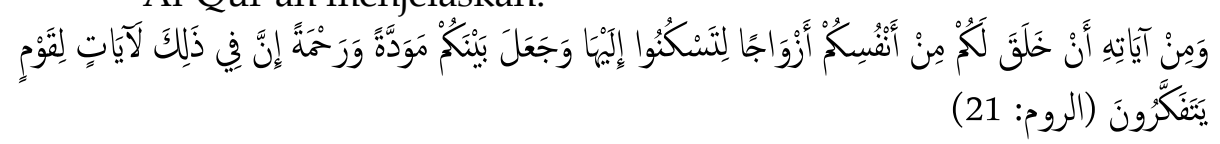

Dan di antara tanda-tanda kekuasaan-Nya ialah Dia menciptakan untukmu istri-istri dari jenismu sendiri, supaya kamu cenderung dan merasa tenteram kepadanya, dan dijadikannya di antaramu rasa kasih dan sayang. Sesungguhnya pada yang demikian itu benar-benar terdapat tanda-tanda bagi kaum yang berpikir. (QS. Al-Rum : 21)

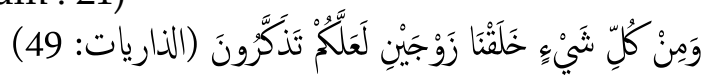

Dan segala sesuatu Kami ciptakan berpasang-pasangan supaya kamu mengingat kebesaran Allah. (QS. Al-Dzariyat:49)

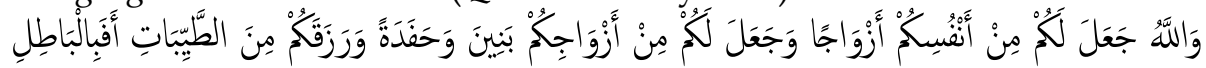

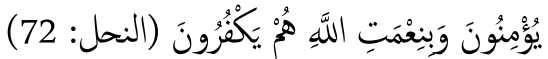

Allah menjadikan bagi kamu isteri-isteri dari jenis kamu sendiri dan menjadikan bagimu dari isteri-isteri kamu itu, anak-anak dan cucu-cucu, dan memberimu rezki dari yang baik-baik. Maka mengapakah mereka beriman kepada yang bathil dan mengingkari nikmat Allah ?" (Al-Nahl : 72)

Ada beberapa hikmah menikah, pertama : menjaga seseorang dan pasangannya terjatuh pada perbuatan haram, semisal zina dan lainnya. Kedua: menjaga keturunan dari ketergelinciran (dengan didikan dan bimbingan). Ketiga : tetap dan jelasnya nasab atau keturunan. Keempat: membina keluarga untuk membangun masyarakat yang baik. Kelima: mewujudkan tolong menolong antara individunya.

Menurut ulama rukun-rukun nikah ada lima yakni: calon suami, calon istri, wali nikah, dua orang saksi, dan shighat. Yang dimaksud sighat ini adalah ijab dan kabul. Ijab adalah ucapan dan ungkapan menikahkan, seperti "aku menikahkan dirimu dengan anak perempuanku". Sedangkan kabul merupakan ucapan balasan dari mempelai pria seperti : "saya terima nikahnya".

Dalam pernikahan diwajibkan adanya mahar atau maskawin demi menyempurnakan akad pernikahan dimaksud. Mahar ini bisa 
saja disebutkan dalam akad, boleh juga tidak disebutkan secara detail atau tidak. Hal ini sebagaimana yang termaktub dalam al-Qur'an ${ }^{4}$ :

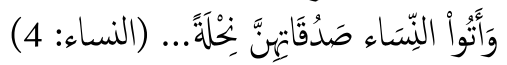

Berikanlah maskawin (mahar) kepada wanita (yang kamu nikahi) sebagai pemberian dengan penuh kerelaan

Ketika melaksanakan akad nikah dilakukan maka disunnahkan melakukan beberapa hal berikut : pertama, khitbah atau lamaran (peminangan) dilakukan sebelum pernikahan. Kedua, mendoakan kedua mempelai dengan harapan semoga mendapatkan kebahagiaan dan kesempurnaan dalam pernikahannya.

Ketiga, mengumumkan akad pernikahan, menampakkan kegembiraan dengan memukul rebana dan mengumpulkan masyarakat supaya terekspos. Dengan demikian maka merahasiakan pernikahan adalah perbuatan makruh. Anjuran mengumumkan pernikahan ini berdasarkan pada hadits Rasul saw :

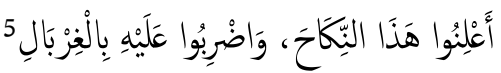

Umumkanlah oleh kalian pernikahan ini, dan tabuhkanlah rebana

Keempat, membaca doa ketika melakukan hubungan intim dengan pasangan, sehingga ketika seseorang memiliki niat untuk menggauli istrinya maka dianjurkan membaca doa :

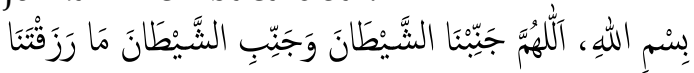

Dengan menyebut nama Allah. Ya Allah Jauhkanlah (hindarkanlah) setan dari kami dan jauhkanlah seta dari apa yang engkau anugerahkan (yakni anak)

\section{Aspek Sosiologis pada Walimah Pernikahan}

Lumrahnya sebuah pernikahan maka biasanya dirayakan dengan menyelenggarakan walimah. Walimah sebagaimana kita ketahui bersama sebagaimana kita ketahui sebagai pesta pernikahan. Adapun walimah secara bahasa diambilkan dari المَلْمُ yang bermakna berkumpul. Dinamakan walimah sebab dalam acara itu sepasang mempelai suami istri berkumpul dalam satu acara dan satu ikatan pernikahan.

\footnotetext{
${ }^{4}$ Mustafa al-Khin, Al-Fiqh al-Manhaji ala Madzhab al-Imam al-Syafi'i, (Maktabah Syamilah, tt.), IV, 75

${ }^{5}$ Muhammad ibn Yazid, Sunan Ibn Majah (Maktabah Syamilah, tt.), I, 611
} 
Namun dalam kamus arab, disebutkan bahwa makna walimah adalah makanan pesta pernikahan atau setiap makanan yang dibuat untuk mengundang orang lain. Hukum melakukan walimah ini adalah sunnah muakkad. Hal ini sebagai kesimpulan dari tegasnya perintah melakukan walimah dari rasul, baik secara ucapan maupun secara perbuatan.

Dalam sebuah hadits disebutkan bahwa:

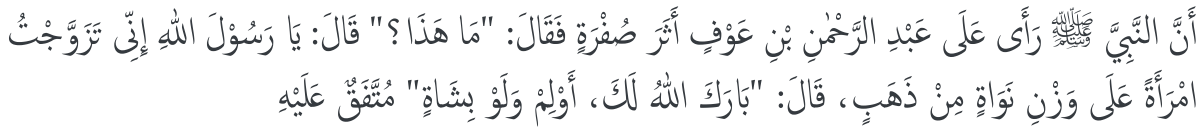

Rasul saw melihat bekas kekuningan pada Abdurrahman bin Auf. Lalu Rasul bertanya, "Apa ini?" Ia menjawab: "Wahai Rasul, sesungguhnya aku telah menikahi seorang perempuan dengan maskawin senilai satu biji emas. Beliau bersabda: "Semoga Allah memberkahimu, adakan perayaan walimah walaupun hanya dengan seekor kambing." (Muttafaq Alaih). ${ }^{6}$

Dari hadits ini disimpulkan bahwa pernikahan harus dirayakan dengan mengundang orang banyak. Tentu sebelumnya dengan menyiapkan makanan untuk para undangan. Makanya Rasul saw meminta kepada sahabat Abdurrahman ibn 'Auf untuk menyembelih seekor kambing, tak lain untuk menyediakan makanan bagi para undangan yang hadir dalam acara walimah ini.

Dalam perhelatan walimah ini pastinya merupakan acara berkumpul, bercengkrama dengan sesama anggota masyarakat. Bahkan acara walimah ini semacam acara makan besar. Saat masyarakat berkumpul dengan judul pernikahan seseorang maka secara langsung merupakan pengumuman terbukan bahwa kedua mempelai sudah sah sebagai suami istri sehingga tidak perlu lagi bertanya-tanya ketika keduanya selalu bersama. Dengan demikian tidak ada lagi fitnah, isu dan lainnya karena statusnya jelas, sebagai pasangan suami istri.

Berbeda halnya bila keduanya tidak jelas apalagi tidak diketahui secara pasti status kedua mempelai. Maka secara sosiologis keduanya akan menjadi bahan gunjingan yang menjadi riak-riak ketidakharmonisan sesama anggota masyarakat. Hal ini wajar karena memang masyarakat tidak mengetahui pasti status keduanya, apakah

${ }^{6}$ Muhammad ibn Ismail al-Bukhari, Shahih al-Bukhari, (Maktabah Syamilah, tt.), III, 53. Hadits ke 2049 
pasangan sah atau bukan. Karena kebaikan tidak selalu mesti disembunyikan dalam konteks tertentu maka wajib halnya dipamerkan, diumumkan supaya tidak ada desas-desus yang akhirnya menjadi pemantik konflik.

Jika kedua mempelai sudah diketahui secara pasti sebagai pasangan yang sah, maka anak turunannya juga menjadi generasi yang baik, dan mendapat sambutan yang baik dari lingkungan. Sebab ia lahir dari hubungan yang sah. Tentu tidak sama jika si anak lahir dari pasangan yang tidak jelas keabsahan nikahnya. Dalam situasi seperti ini si anak akan diragukan garis nasabnya. Bahkan bisa-bisa si anak dicap sebagai anak haram, yang akan menjadi bahan bully-an sepanjang hidupnya. Padahal si anak hanya korban dari perkawinan kedua orangtuanya, tetapi ia yang harus menanggung gunjingan bahkan hujatan masyarakat dengan cap anak haram yang menempel padanya.

Tidak hanya sampai di sini saja, prosesi walimah ini juga sebagai ajang mempererat tali jiwa di antara sesama anggota masyarakat. Ini adalah momen yang sangat berharga apalagi dengan gaya hidup masyarakat zaman sekarang yang semakin mengarah pada individualistis, yang hanya memikirkan diri sendiri sehingga lupa untuk bertegur sapa, berbagi rasa dan lainnya. Prosesi walimah inilah salah satu forum yang bisa memecahkan persoalan ini.

\section{Bahaya Nikah Siri}

Selama ini di masyarakat ada beberapa asumsi tentang nikah siri. Asumsi ini terbangun atas ketidakjelasan dan beragamnya praktik pernikahan yang dinilai tidak wajar yang terjadi di masyarakat. Pertama, nikah siri dianggap sama dengan nikah tanpa wali. Pernikahan ini dilakukan secara siri atau rahasia. Hal ini terjadi karena wali mempelai wanita tidak menyetujui pernikahan ini. Boleh jadi karena merasa tidak sreg dengan mempelai pria. Atau mungkin saja si ayah sudah memiliki calon bagi si anak perempuannya, sehingga si ayah bermaksud menjodohkannya dengan pria pilihan si ayah. Oleh karena itulah, pernikahan dilakukan tanpa restu dan tanpa sepengetahuan si ayah atau si wali. Makanya, karena dilakukan secara sembunyi-sembunyi maka masyarakat menyebutnya sebagai nikah siri. 
Kedua, nikah siri adalah nikah yang sah secara agama atau adat namun tidak tercatat di KUA (Kantor Urusan Agama). Pernikahan ini tidak ada masalah secara agama, karena sudah memenuhi syarat dan rukun nikah. Pernikahan ini dilakukan dengan kehadiran kedua mempelai, wali nikah, dua orang saksi dan ijab kabul. Yang menjadi problem bagi masalah ini adalah karena pernikahan ini tidak tercatat di KUA. Tentu secara otomatis kedua mempelai tidak mendapatkan buku nikah. Nikah ini juga disebut dengan nikah di bawah tangan. Oleh masyarakat, pernikahan ini juga disebut sebagai nikah siri. Di antara dua asumsi masyarakat di atas, bentuk kedua yang lebih pas disebut dengan nikah siri.

Meskipun nikah siri ini sah secara hukum Islam, tetap saja menurut hukum positif Indonesia dinilai sebagai pernikahan illegal. Praktik pernikahan di negara ini (Indonesia) telah diatur dalam Undang-undang nomor 1 tahun 1974 dan inpres Nomor 1 tahun 1991 Kompilasi Hukum Islam (KHI). Kedua aturan tersebut menyebutkan bahwa:

"Tiap-tiap perkawinan dicatat menurut peraturan perundangundangan yang berlaku." (Ayat 2 Pasal 2 Undang-undang Nomor 1 tahun 1974$)^{7}$

Agar terjamin ketertiban perkawinan bagi masyarakat Islam setiap perkawinan harus dicatat. (Ayat 1 pasal 5 Kompilasi Hukum Islam) 8

Pencatatan perkawinan tersebut apada ayat (1), dilakukan oleh Pegawai Pencatat Nikah sebagaimana yang diatur dalam Undang-undang No.22 Tahun 1946 jo Undang-undang No. 32 Tahun 1954. (Ayat 2 pasal 5 Kompilasi Hukum Islam)

Kedua pasal di atas menegaskan bahwa pernikahan harus dicatatkan ke dalam dokumen negara, dalam hal ini dilakukan oleh Kantor Urusan Agama. Hal itu dilakukan supaya ada jaminan pada pernikahan yang dilakukan masyarakat diatur secara tertib. Dengan demikian tatanan masyarakat akan terhindar dari kesemrawutan. Hanya saja kewajiban pencatatan ini banyak diabaikan oleh pelaku nikah siri, sehingga mengakibatkan kecelakaan hak perdata bagi istri dan anak.

\footnotetext{
7 Undang-undang Nomor 1 Tahun 1974

8 Instruksi Presiden Nomor 1 Tahun 1991, Kompilasi Hukum Islam
} 
Nikah siri yang terjadi mengakibatkan banyak efek negatif, pertama, keraguan masyarakat atas keabsahan pernikahan tersebut. Selain itu negara menilai bahwa pernikahan ini illegal secara hukum. Karena dalam terminologi peraturan perundang-undangan, sebuah pernikahan dinyatakan legal bila dicatat oleh kantor urusan Agama atau kantor catatan sipil. Ketika ikatan keabsahan pernikahan ini diragukan, maka tentu diragukan pula keabsahan garis nasab si anak. ${ }^{9}$

Kedua, si anak hanya memiliki hubungan perdata dengan ibu dan keluarga ibunya saja, sedangkan hubungan perdata dengan si ayah tidak ada, Padahal si anak adalah hasil perkawinan si ayah dan ibu. Dengan kata lain bahwa si anak tidak dapat menuntut hak-haknya dari si ayah. Oleh karena itu dalam pernikahan siri ini si anak lahir menjadi korban. Dengan dilahirkan tanpa dokumen pernikahan yang jelas maka kelahiran si anak sudah pasti tidak dicatatkan dalam akta. Kalaupun mendapatkan akta kelahiran, maka nama si ayah tidak tertulis dalam dokumen tersebut.

Ketiga, akibat pernikahan siri maka istri dan anak tidak bisa menuntut hak nafkah dan hak waris. Hal ini terjadi sebab si istri dan anak tidak memiliki dokumen pernikahan sebagai bukti bahwa ia adalah istri dan anak. Maka aparat penegak hukum seperti pengadilan atau kepolisian tidak berdaya menyelesaikan sengketa waris, sebab tidak memiliki alat bukti yang cukup. Mungkin saja tidak selalu terjadi sengketa waris, tapi bukti nyata terjadi bahwa sengketa banyak terjadi sepeninggal si suami. ${ }^{10}$

\section{Alasan Perilaku Nikah Siri Masyarakat Pamekasan sebelum Akad Nikah di Hadapan Pejabat KUA}

Masyarakat Pamekasan sebagaimana layaknya masyarakat muslim lainnya merupakan warga yang taat hukum agama dan hukum positif, hanya saja masih saja terjadi anomali sosial dan hukum di sana sini. Salah satu kemusykilan yang terjadi adalah pernikahan siri yang dilakukan sebelum akad nikah secara resmi di hadapan pejabat KUA. Ada beberapa alasan yang melatarbelakangi terjadinya fenomena tersebut.

\footnotetext{
${ }_{9}^{9}$ Vivi Kurniawati, Nikah Siri, (Jakarta Selatan, Rumah Fiqih Publishing, 2019), 30.

${ }^{10}$ Vivi Kurniawati, Nikah Siri, 30
} 
Pertama, pernikahan siri dilakukan untuk menghindari terjadinya hubungan haram sebelum pernikahan resmi digelar. Fakta ini terjadi karena asumsi masyarakat yang menganggap bahwa ikatan pertunangan sudah selayaknya suami istri, yang bebas melakukan hubungan badan sekalipun. Sehingga daripada terjatuh pada perbuatan haram maka akad pernikahan pun disegerakan. Setelah itu diakad lagi oleh pihak KUA sebagaimana jadwal pernikahan yang sudah direncanakan jauh-jauh hari. ${ }^{11}$

Kedua, pernikahan siri dilakukan sebagai upaya protektif bagi kedua mempelai supaya tidak melakukan hubungan seksual sebelum menikah. Hal ini dengan pertimbangan semakin tidak terkendalinya pergaulan bebas dan mudahnya mengakses konten pornografi yang menuntut pengendalian diri yang kokoh. Bagi orang tua mempelai ini adalah tantangan berat, makanya mereka tidak ambil risiko sehingga menikahkan kedua mempelai. Hal ini agak mirip dengan motif yang pertama, hanya saja berbeda. Motif pertama karena asumsi keliru, sedangkan motif kedua karena godaan media-media dan konten negatif. 12

Ketiga, pernikahan siri dilakukan sebagai upaya pengikat bagi kedua mempelai supaya segera terwujud sebagai suami istri dengan ikatan pernikahan yang sah. Biasanya sebelum akad pernikahan dilakukan pihak orang tua kedua mempelai merasa waswas khawatir kedua mempelai tidak jadi berjodoh. Sehingga dilangsungkanlah pernikahan untuk menghilangkan rasa waswas tersebut. ${ }^{13}$ Dari ketiga faktor ini, yang sering dijadikan alasan oleh masyarakat adalah yang ketiga.

Perilaku nikah siri dengan model seperti yang telah dijelaskan, dalam pandangan hukum Islam, tidak bermasalah. Hanya saja jika di akad kembali di hadapan pejabat KUA maka berarti si mempelai telah diakad dua kali. Akad nikah yang kedua bisa dikategorikan sebagai tajdid al-Nikah atau pembaruan akad nikah. Pernikahan model ini bila

11 Samsurya, Masyarakat Pamekasan, Wawancara Langsung, (Pamekasan, 24 Juli 2021).

12 Alimin, Masyarakat Pamekasan, Wawancara Langsung, (Pamekasan, 21 Juli 2021).

13 Sulastri, Masyarakat Pamekasan, Wawancara Langsung, (Pamekasan, 10 Juli 2021). 
dilandaskan pada kekhawtiran terjerumus pada lembah zina bisa juga selaras dengan Maqashid Syariah atau tujuan-tujuan diturunkannya syariat, yakni hifdz al-Nasl (menjaga keturunan).

\section{Kesimpulan}

Dari sekian pembahasan alasan Perilaku Nikah Siri Masyarakat Pamekasan sebelum Akad Nikah di Hadapan Pejabat KUA ada tiga yakni: pertama, untuk menghindari terjadinya hubungan haram sebelum pernikahan resmi digelar sebab asumsi masyarakat yang keliru tentang pertunangan yang menganggap hubungan sah suami istri. Kedua, menyelamatkan kedua mempelai dari pengaruh pergaulan bebas dan media konten negatif yang mengaibatkan pada atifitas terlarang. Ketiga, untuk mengikat kedua mempelai supaya segera terwujud sebagai suami istri dengan ikatan pernikahan yang sah

\section{Daftar Pustaka}

Al-Bukhari, Muhammad ibn Ismail, Shahih al-Bukhari, (Maktabah Syamilah, tt.)

Al-Ghazi, Muhammad ibn Qasim, Fathul al-Qarib, (Maktabah Syamilah, tt.)

Al-Khin, Mustafa, Al-Figh al-Manhaji ala Madzhab al-Imam al-Syafi'i, (Maktabah Syamilah, tt.), IV, 75

Al-Zuhaily, Wahbah, Al-Figh al-Islami wa Adillatuh, (Maktabah Syamilah, tt.)

Instruksi Presiden Nomor 1 Tahun 1991, Kompilasi Hukum Islam

Kurniawati, Vivi, Nikah Siri, (Jakarta Selatan, Rumah Fiqih Publishing, 2019)

R, M. Dahlan, Fikih Munakahat, (Yogyakarta: Deepublish, 2016)

Undang-undang Nomor 1 Tahun 1974

Yazid, Muhammad ibn, Sunan Ibn Majah (Maktabah Syamilah, tt.)

\section{Wawancara :}

Alimin, Masyarakat Pamekasan, Wawancara Langsung, (Pamekasan, 21 Juli 2021). 
Asyhari

Samsurya, Masyarakat Pamekasan, Wawancara Langsung, (Pamekasan, 24 Juli 2021).

Sulastri, Masyarakat Pamekasan, Wawancara Langsung, (Pamekasan, 10 Juli 2021). 